\title{
Delimitacja przygranicznych obszarów problemowych The delimitation of problem border areas
}

\author{
Tomasz Komornicki, 2 (I) Rafał Wiśniewski ${ }^{1}$ (D) Andrzej Miszczuk ${ }^{3}$ (D) \\ ${ }^{1}$ Instytut Geografii i Przestrzennego Zagospodarowania im. Stanisława Leszczyckiego PAN \\ ul. Twarda 51/55, 00-818 Warszawa \\ ${ }^{2}$ Uniwersytet Marii Curie-Skłodowskiej, Wydział Nauk o Ziemi i Gospodarki Przestrzennej \\ al. Kraśnicka 2d, 20-718 Lublin \\ ${ }^{3}$ Uniwersytet Marii Curie-Skłodowskiej, Wydział Ekonomiczny \\ pl. Marii Curie-Skłodowskiej 5, 20-031 Lublin \\ t.komorn@twarda.pan.pl•rafwis@twarda.pan.pl•andrzej.miszczuk@poczta.umcs.lublin.pl
}

\begin{abstract}
Zarys treści. Obszary przygraniczne postrzegane są zazwyczaj jako obszary peryferyjne, o niższym stopniu rozwoju gospodarczego. Jednak położenie przygraniczne może przynosić również wymierne korzyści. W niniejszym artykule skupiono uwagę na dwóch elementach: tj. (1) delimitacji obszarów przygranicznych; (2) podziale jednostek, dla których położenie przy granicy państwowej przynosi pozytywne i negatywne skutki gospodarcze. Delimitację przeprowadzono z uwzględnieniem rzeczywistych powiązań gospodarczych. W pierwszym etapie procedura delimitacyjna obejmowała wyznaczenie obszaru przygranicznego składającego się z pasa dwóch gmin. Drugi etap procedury polegał na eliminowaniu z tego zbioru jednostek o korzystnym położeniu względem ośrodków regionalnych wewnątrz kraju (uznano, że bliskość tych ośrodków niweluje potencjalne negatywne oddziaływanie granicy) oraz o wysokiej wartości eksportu do kraju sąsiedniego (uznano, że są to jednostki, które na położeniu przygranicznym raczej zyskują niż tracą). W ten sposób wyodrębniono gminy przygraniczne-problemowe, które wymagają potencjalnego wsparcia rozwojowego. Obejmują one przede wszystkim obszary leżące wzdłuż granicy z Rosją, Litwą, Białorusią i Słowacją. W największym stopniu na położeniu przygranicznym zyskują gminy leżące wzdłuż granicy polsko-niemieckiej. Autorską propozycję delimitacji przedstawiono na tle innych funkcjonujących podziałów. Przedstawiono również rekomendacje dla polityki rozwoju regionalnego.
\end{abstract}

Słowa kluczowe: granica, obszary problemowe, handel zagraniczny, dostępność przestrzenna, polityka spójności.

\section{Wstęp}

Położenie przygraniczne może mieć różnorodny wpływ na rozwój i konkurencyjność gospodarczą obszarów przygranicznych. W wielu opracowaniach, bazujących na przykładach z różnych części Europy i świata, znajdziemy potwierdzenie zarówno pozytywnych, jak i negatywnych efektów takiej lokalizacji. Korzyści z przygranicznego położenia mogą być rozpatrywane w skali lokalnej mikroskali (np. handel przygraniczny, turystyka zakupowa; Jałowiecki, 1999; Spierings i van der Velde, 2008, Powęska, 2011; obsługa ruchu transgranicznego; rozwój usług ukierunkowany na obywateli krajów sąsiednich; Ciok, 2004), transgraniczne migracje ludności i firm prowadzonych przez osoby fizyczne (Skraba i Nowicka, 2018) jak i na wyższym poziomie instytucjonalnej współpracy transgranicznej (sieci powiązań) (Dołzbłasz, 2017, 2018). Negatywne skutki oddziaływania granicy wiązane 
są zazwyczaj ze wzrostem przestępczości (Jałowiecki, 1999; Szymańska i Stefaniak, 2014) oraz z peryferializacją społeczno-gospodarczą obszaru (Miszczuk, 2013). Tym samym ich efekt jest najczęściej lokalny lub regionalny. Co istotne, zarówno pozytywne jak i negatywne skutki oddziaływania granic państwowych na obszary przyległe mogą być odczuwalne równocześnie (Dołzbłasz, 2015). Charakter tych oddziaływań może być inny dla poszczególnych grup społecznych lub dla różnych branż podmiotów gospodarczych.

Kierunek rozwoju obszarów przygranicznych wyznacza w znacznym stopniu funkcja granicy tzn. fakt czy jest ona granicą otwartą o dużym stopniu przenikalności, gdzie tworzy się swoista strefa kontaktu, czy też granicą zamkniętą o niskim stopniu przenikalności i utrudnionym przepływie ludzi, towarów oraz idei. Ze względu na istnienie granicy państwowej, obszary po obu jej stronach mogą rozwijać się w różnym tempie, co w konsekwencji może prowadzić do asymetrii układu społeczno-gospodarczego (Więckowski, 2010; Jakubowski, 2018). Funkcjonowanie obszarów przygranicznych zależy z jednej strony od wewnętrznej polityki danego państwa, a z drugiej od relacji z państwami sąsiadującymi (Rajman, 1993; Miszczuk, 2013; Komornicki i Wiśniewski, 2017).

Bardzo często obszary przygraniczne są postrzegane jako obszary peryferyjne, przede wszystkim poprzez pryzmat fizycznego oddalenia od centrów rozwoju gospodarczego (Koter, 2003; Miszczuk, 2013; Proniewski, 2014; Jakubowski i Bronisz, 2015). Oddalenie to przyczynia się również do tzw. efektu gasnącej fali, czyli ograniczonej ilości impulsów rozwojowych docierających na peryferie z centrów rozwoju gospodarczego danego kraju (Gałązka i Mync, 1999). Mogą też wystąpić - w warunkach pełnego otwarcia granicy - efekty: kohezji (kontynuacji), wykluczenia, drenażu (przeskoku) lub „wyspy” (Miszczuk, 2013). Peryferyjność obszarów przygranicznych, skutkująca m.in. niskim poziomem rozwoju gospodarczego, zmusza do prowadzenia odrębnej polityki na różnych poziomach hierarchicznych (od szczebla krajowego po lokalny). Również na poziomie Unii Europejskiej (UE) dostrzega się negatywne skutki pogłębiającej się polaryzacji przestrzennej. Powstają dedykowane programy wsparcia obszarów problemowych mające na celu zmniejszanie zróżnicowań ekonomicznych i społecznych między regionami UE. W związku z tym istotna staje się właściwa delimitacja obszarów problemowych, w tym problemowych obszarów przygranicznych. Obszary przygraniczne wskazano także jako jeden z rodzajów obszarów funkcjonalnych w Koncepcji Przestrzennego Zagospodarowania Kraju 2030 (przyjętej w roku 2011). Koncepcja kwalifikowała je do kategorii obszarów wymagających restrukturyzacji i rozwoju nowych funkcji przy wsparciu instrumentów właściwych polityce regionalnej. Oznaczało to, że są one potencjalnymi obszarami strategicznej interwencji (OSI), a zarazem, że konieczna jest ich delimitacja. Koncepcja wskazywała jednak jednocześnie, że specyfika problemów charakteryzujących obszary przygraniczne wymusza zintegrowane podejście w ramach polityki przestrzennego zagospodarowania kraju i polityki regionalnej na każdym poziomie programowania i zarządzania (KPZK 2030, 2012). Bardzo często zasięg obszarów przygranicznych, wyznaczony na potrzeby realizacji polityki rozwoju regionalnego, nie odzwierciedla faktycznych powiązań transgranicznych (przykładem może być przebieg granicy obszaru wsparcia Programu Współpracy Transgranicznej Rzeczpospolita Polska - Republika Słowacka na jej północno-wschodnim odcinku). Typologia obszarów przygranicznych stosowana wyjściowo w KPZK 2030 ma z kolei charakter czysto geograficzno-polityczny. Wyróżnia dwa rodzaje obszarów położonych przy wewnętrznych oraz zewnętrznych granicach UE. Takie definiowanie i delimitowanie obszarów przygranicznych pozostaje w oderwaniu od ich faktycznej sytuacji społeczno-gospodarczej (bi- 
lansu opisywanych w literaturze i wspomnianych wyżej, pozytywnych oraz negatywnych skutków oddziaływania granicy państwowej), a zarazem od realnej potrzeby interwencji strategicznej.

Celem artykułu jest alternatywna propozycja delimitacji obszarów przygranicznych wykonana z perspektywy negatywnego oddziaływania granicy państwowej. Główną ideą jest więc identyfikacja tych obszarów przygranicznych, dla których położenie przy granicy państwowej jest barierą rozwojową. Można to utożsamiać z próbą wyznaczenia stref wymagających różnych form wsparcia na poziomie europejskim, krajowym lub regionalnym. Takie ujęcie determinuje oparcie delimitacji na prostych wskaźnikach możliwych do stosowania przez odpowiednie władze w formie monitoringu. Analizę przeprowadzono na przykładzie granic Polski uwzględniając interakcje transgraniczne związane z międzynarodowymi powiązaniami handlowymi (eksport towarów) oraz położenie jednostek w obrębie kraju (dostępność do najważniejszych regionalnych rynków pracy oraz do usług wyższego rzędu). Tak sformułowany cel główny ma zatem przede wszystkim charakter metodyczny. Cele uzupełniające to: a) prezentacja wyników zastosowanej metody delimitacji na przykładzie Polski oraz b) propozycja alternatywnego podejścia w realizacji polityk rozwojowych o charakterze przestrzennym.

W kolejnych podrozdziałach artykułu, jako szerszy kontekst badań, przeanalizowano ewolucję funkcji granic (uznając je za element determinujący oddziaływanie na rozwój społeczno-gospodarczy obszarów przygranicznych) oraz kontekst instytucjonalny (instrumenty polityki regionalnej i polityki spójności względem obszarów przygranicznych). Oddzielnie scharakteryzowano powszechnie stosowane sposoby delimitacji obszarów przygranicznych. Na tym tle przedstawiono założenia metodyczne proponowanej delimitacji problemowych obszarów przygranicznych oraz rezultaty analizy na przykładzie granic Polski. Całość kończy podsumowanie zawierające rekomendacje dla ewentualnych działań publicznych skierowanych na niwelowanie negatywnych efektów sąsiedztwa granicy państwowej.

\section{Ewolucja funkcji granic}

Od drugiej połowy XX w. granice postrzegane są coraz powszechniej jako bariery przestrzenne dla interakcji. Pojawienie się podejścia funkcjonalnego $\mathrm{w}$ badaniu granic $\mathrm{V}$. Kolosov (2005) datuje na początek lat 50., kiedy to zakwestionowano wyłącznie negatywny wpływ istnienia granicy na podstawy rozwojowe terenów przyległych. Już W. Christaller (1963) twierdził, że ośrodki centralne położone przy stabilnej granicy mogą czerpać korzyści z rozwoju handlu, magazynowania itd. A.L. Sanguin (1983) wyróżnił trzy rodzaje obszarów przygranicznych: (a) "luki” przygraniczne (niezagospodarowane), (b) „mgławice” przygraniczne (rozproszone osadnictwo o znikomych powiązaniach), (c) regiony przygraniczne (silne powiązania transgraniczne). Z czasem, na terenie Europy jednym z głównych tematów badawczych geografii politycznej stały się pełnione przez granice funkcje (Komornicki, 1999; Bartz i Fuchs-Schündeln, 2012; Cooper i Perkins, 2012), a w konsekwencji także przepływy ludności i towarów (Komornicki, 2002, 2010a; Powęska, 2002; Szejgiec, 2010; Wiśniewski, 2010). Funkcje badano także wcześniej (Harsthorne, 1933), ale były to często analizy o charakterze wtórnym (np. oceniające trafność wyznaczonego przebiegu). Tym razem, granicę zaczęto postrzegać jako „mobilną” (mobile border), czego 
implikacją był tymczasowy charakter funkcjonowania barier dla przepływów. Przewidywano ich stopniową redukcję w miarę postępu procesów integracji przestrzennej. Badania granic zaczęły być prowadzone na gruncie rożnych dyscyplin i stopniowo rozszerzały swoje pole analiz na całe obszary przygraniczne i transgraniczne (por. Garcia, 2003). Zacieśnianie integracji oraz rozszerzanie się UE stanowiło potwierdzenie tak postawionych założeń.

Współcześnie, w związku z ewolucją funkcji granic, coraz częściej postrzega się je jako pewien zasób (np. Knotter, 2014; Sohn, 2014), który może stanowić jeden z endogenicznych elementów rozwoju regionów przygranicznych. Zauważalny jest również proces zmiany charakteru współczesnych granic państwowych. Następuje ich przesunięcie przestrzenne poza wytyczone granice polityczne (np. kontrole graniczne w portach lotniczych), co jest efektem wprowadzania „świata bez granic” (np. w strefie Schengen można być poddanym kontroli nie tylko na zewnętrznej granicy strefy, ale w jakimkolwiek miejscu tej strefy) (Kolosov i Więckowski, 2018). Z drugiej jednak strony granice nadal stanowią realne (głównie polityczno-prawne ale nieraz także fizyczno-infrastrukturalne) bariery różnorodnych przepływów transgranicznych. Bilans korzyści i niekorzyści nie jest jednoznaczny. Z całą pewnością jest też zróżnicowany terytorialnie, co nie zawsze było brane pod uwagę w dotychczasowych badaniach.

W Europie Środkowo-Wschodniej, w tym w Polsce, pełne otwarcie granic wewnątrz Unii Europejskiej oznaczało de facto likwidację na granicach wewnętrznych specyficznej granicznej infrastruktury transportowej (rozumianej m.in. jako przejścia graniczne, terminale celne itd.; Komornicki, 2010b). Tym samym o możliwościach rozwoju wzajemnych relacji społeczno-ekonomicznych sąsiadujących krajów decydować zaczęła rzeczywista infrastruktura transgraniczna, którą rozumiemy jako fizyczne istnienie przecinających granice szlaków drogowych i kolejowych oraz jakość (standard) tych tras (Komornicki, 1999). Jednocześnie na granicy zewnętrznej UE funkcja bariery została zachowana, a nawet wzmocniona. Siła powiązań transgranicznych pozostała tam uzależniona od czynników formalno-prawnych. Takie warunki nie muszą jednak oznaczać niekorzystnego wpływu na lokalny rozwój gospodarczy. W ocenie tego wpływu pomocna stała się analiza przestrzenna intensywności społeczno-gospodarczych interakcji dwustronnych. Badano m.in. intensywność handlu z krajem sąsiednim w relacji do odległości czasowej od najbliższego przejścia granicznego do tego kraju. Wyniki nie były jednoznaczne. Dla zbioru wszystkich jednostek (w tym wypadku polskich powiatów) zależność była słaba. Po odrzuceniu jednostek o największej koncentracji wymiany wskaźniki korelacji wzrastały. Uznano to za dowód, że bliskość granicy może być ważnym zasobem dla mniejszych podmiotów gospodarczych, a tym samym dla ogólnie słabszych „gospodarek lokalnych”. Jednocześnie duże przedsiębiorstwa w coraz większym stopniu funkcjonują w przestrzeni globalnej, gdzie koszty związane z transportem i pokonywaniem barier przestrzennych są redukowane (Komornicki i inni, 2015).

\section{Obszary przygraniczne w świetle polityki spójności}

Agenda Terytorialna 2020 zdefiniowała wyzwania dla rozwoju terytorialnego Unii Europejskiej. W kontekście relacji transgranicznych, jako wyzwania uznano m.in.:

- rosnące zagrożenie globalizacją - zmiany strukturalne po światowym kryzysie gospodarczym; 
- wyzwania związane z integracją w UE i coraz większą współzależnością regionów (Territorial Agenda, 2011, s. 3-4).

W przeciwieństwie do wcześniejszych dokumentów (Agenda Terytorialna UE z 2007 r.) na rosnące zależności regionów, w tym zależności w wymiarze lokalnym (transgranicznym), spojrzano przez pryzmat mogących ujawnić się zagrożeń dla rozwoju lokalnego. Z punktu widzenia relacji transgranicznych istotne wydają się trzy priorytety dotyczące bezpośrednio integracji w ponadnarodowych regionach funkcjonalnych (priorytet 3), usprawnienia powiązań terytorialnych (wymiar transportowy, priorytet 5) oraz zapewnienia globalnej konkurencyjności regionów (priorytet 4). Wprowadzenie do Traktatu Lizbońskiego spójności terytorialnej, jako trzeciego wymiaru spójności obok ekonomicznej i społecznej, stało się wskazówką dla poszukiwania źródeł rozwoju lokalnego w zasobach endogenicznych. Do zasobów takich zaliczyć można również specyficzne cechy położenia geograficznego, w tym niekiedy położenie przygraniczne. Tym samym przygraniczność nie musi być utożsamiana z peryferyjnością, a tym bardziej „problemowością” określonych obszarów. Takie podejście jest jedną z przesłanek dla poszukiwania nowych wskaźników obrazujących sytuację lokalnych gospodarek, a także oceniających siłę i charakter relacji transgranicznych. Jest to zgodne z założeniami podejścia zorientowanego terytorialnie (place based policy) (Barca, 2009) i postulatem wzmocnienia terytorialnych wymiarów polityk sektorowych (Camagni, 2011). Oznacza to np. przesunięcie głównych akcentów polityki inwestycyjnej w transporcie drogowym z sieci transeuropejskich w kierunku powiązań wewnątrzkrajowych i sieci dróg drugorzędnych. W opracowaniu Territorial State and Perspectives of the European Union (Damsgaard i inni, 2011), będącym podstawą merytoryczną dla Agendy Terytorialnej 2020, zwrócono uwagę na odmienne efekty poszczególnych inwestycji (mierzone dostępnością przestrzenną) z punktu widzenia europejskiego, krajowego i regionalnego. W Raporcie Bazowym Polskiej Prezydencji (Böhme i inni, 2011; Zaucha i inni, 2012) zaproponowano, aby odmienna pozycja poszczególnych regionów w zakresie dostępności na poziomie europejskim i krajowym determinowała skalę i charakter ewentualnego wsparcia w ramach polityki wspólności.

Podstawowym dokumentem kształtującym politykę przestrzenną jest w Polsce nadal, wspomniana wyżej, Koncepcja Przestrzennego Zagospodarowania Kraju 2030. Z punktu widzenia relacji transgranicznych, spośród 6 głównych celów rozwojowych wylistowanych w tym dokumencie, istotna jest w szczególności poprawa spójności wewnętrznej kraju (m.in. poprzez wykorzystanie potencjału wewnętrznego wszystkich terytoriów; cel 2) i poprawa dostępności terytorialnej kraju w różnych skalach przestrzennych (cel 3). Pewne znaczenie ma również cel pierwszy (podwyższenie konkurencyjności głównych ośrodków miejskich Polski w przestrzeni europejskiej poprzez ich integrację funkcjonalną), ponieważ duże inwestycje infrastrukturalne przecinające granice, służą jednocześnie poprawie dostępności obszarów przygranicznych. Należy też zwrócić uwagę na inne (względem wcześniejszych dokumentów) podejście do rozwoju głównych elementów sieci transportowych. Priorytet dla powiązań międzynarodowych o charakterze kontynentalnym, został w dokumencie zastąpiony silnym wzmocnieniem inwestycji łączących główne ośrodki krajowe (mutual daily accessibility) i działaniami na rzecz poprawy dostępności obszarów peryferyjnych (w tym przygranicznych).

Polityka względem obszarów przygranicznych oraz relacji transgranicznych jest także prowadzona na poziomie regionalnym. Dokumentami kształtującymi politykę przestrzenną są w tym wypadku strategie rozwoju i plany zagospodarowania przestrzennego 
poszczególnych województw. Przykładem może być województwo lubelskie. Na uwagę zasługuje fakt dostrzegania tam atutów w przygranicznym położeniu i możliwość wykorzystanie tego potencjału jako czynnika rozwojowego, m.in. dzięki delimitacji przygranicznego obszaru strategicznej interwencji (OSI). Za cel generalny w Strategii rozwoju województwa lubelskiego z 2002 r. uznano „osiąganie trwałego rozwoju społecznego i gospodarczego poprzez wykorzystanie geograficznego położenia regionu jako platformy współpracy krajów Europy Wschodniej i Zachodniej" (Plan zagospodarowania..., 2002).

Na wszystkie te elementy nakłada się prowadzona od wielu lat (w Polsce od okresu przedakcesyjnego) polityka wsparcia dla samej współpracy transgranicznej (odrębny cel w ramach polityki spójności; INTERREG, EWT). Z uwagi na główne cele (wsparcie samej współpracy) nie można jej utożsamiać z polityką pomocy dla przygranicznych obszarów problemowych. Jej ograniczeniem jest stosunkowo niski budżet. W najnowszych opracowaniach zwraca się uwagę, że oprócz wsparcia współpracy konieczne jest zwiększenie budżetu programów przełamujących peryferyzację obszarów przygranicznych oraz wspierających planowanie transgraniczne (Medeiros, 2018).

Dość powszechnym ograniczeniem dokumentów strategicznych oraz programów operacyjnych jest delimitacja tych obszarów i określenie zakresu interwencji tylko z polskiej perspektywy, bez odpowiedniej koordynacji z działaniami realizowanymi w regionach po drugiej stronie granicy Wyjątkiem jest np. Strategia współpracy transgranicznej województwa lubelskiego, obwodu wołyńskiego, obwodu lwowskiego i obwodu brzeskiego na lata 2014-2020, powstała jako przejaw realizacji Strategii rozwoju województwa lubelskiego w wymiarze transgranicznym. Została ona opracowana w latach 2013-2014 z inicjatywy samorządu województwa lubelskiego, przy współudziale przedstawicieli obwodów: brzeskiego, Iwowskiego i wołyńskiego, pod auspicjami Związku Transgranicznego „Euroregion Bug” oraz przy wsparciu polskiego Ministerstwa Spraw Zagranicznych.

\section{Dotychczas stosowane delimitacje obszarów przygranicznych}

Przedmiotem podejmowanych delimitacji najczęściej jest obszar przygraniczny, czyli wyodrębniony na podstawie przyjętych kryteriów pas terytorium leżący po jednej stronie granicy państwowej. W literaturze przedmiotu najczęściej odróżnia się go od pogranicza, które leży po obu stronach granicy (Więckowski i inni, 2012). Zasięg obszaru przygranicznego bywa różnie delimitowany w zależności m.in. od celu takiej delimitacji (np. realizowanie polityki regionalnej, polityki wsparcia obszarów problemowych, nadawanie szczególnych uprawnień służbom kontrolnym i granicznym oraz osobom zamieszkującym w sąsiedztwie granicy itp.) (por. Węcławowicz i inni, 2006).

W kontekście celu niniejszego opracowania, istotna jest kwestia terminologiczna tj. zdefiniowanie takich pojęć jak region, strefa i obszar przygraniczny. Region przygraniczny obejmuje zazwyczaj największy obszar, większy niż strefa przygraniczna (nadgraniczna). Utożsamiany jest on najczęściej z regionem administracyjnym. Wówczas regionem przygranicznym są jednostki posiadające podmiotowość terytorialną (w przypadku Polski na poziomie NUTS 2), które bezpośrednio przylegają do granicy państwowej. Jednocześnie w wielu opracowaniach (zwłaszcza ogólnoeuropejskich) regionem nazywa się jednostki poziomu NUTS 3, które w Polsce pełnią jedynie funkcje statystyczną. Ich walorem jest dostęp do porównywalnych danych w skali całej Unii Europejskiej (np. PKB). Strefa 
przygraniczna jest mniejsza od regionu i wyznaczana jest na podstawie kryterium administracyjnego i odległości od granicy. Obejmuje najczęściej jednostki administracyjne (głównie LAU 2) oddalone od granicy państwowej nie więcej niż 50 km (por. np. kryteria wyznaczania obszarów objętych małym ruchem granicznym w strefie Schengen). Strefę nadgraniczną w Polsce definiuje ustawa z dnia 12 października 1990 r. o ochronie granicy państwowej. Strefa ta obejmuje pas gmin przyległych do granicy państwowej, w tym również do granicy morskiej. W przypadku, gdy tak wyznaczona szerokość strefy jest mniejsza niż 15 km, wówczas do strefy nadgranicznej włącza się również obszar gmin bezpośrednio sąsiadujących z gminami przyległymi do granicy państwowej (Ustawa..., 1990). Najbardziej nieokreślonym terminem, używanym w literaturze, a także w dokumentach oficjalnych, jest obszar przygraniczny. Trudno też wskazać różnice powierzchniowe między obszarem a regionem przygranicznym ze względu na brak odpowiedniego kryterium wielkości (Raczyk i inni, 2012). Obszar jest pojęciem szerokim, którego specyfikę określa jedynie położenie geograficzne) oraz mniej formalnym niż region, stąd też bardzo często stosowanym.

Mnogość terminów i, w wielu przypadkach, brak precyzyjnych definicji prowadzi do chaosu terminologicznego, który dodatkowo potęguje zamienne, nie zawsze uprawnione, stosowanie tych terminów. W niniejszym artykule posługujemy się terminem obszar przygraniczny dla wyznaczenia terytorium, gdzie zachodzą interakcje transgraniczne (nawiązanie definicji opartych na zasięgu szeroko rozumianej współpracy lub więzi transgranicznych podawanych m.in. przez Więckowskiego, 2004; Fedyka i innych, 2017 oraz Studzienickiego i Palmowskiego, 2019). W tym przypadku termin ten wydaje się najbardziej adekwatny, w odróżnieniu od strefy przygranicznej, która jest wyznaczana na podstawie jasnych kryteriów odległości od granicy. Wyznaczany obszar jest równocześnie zbyt mały, aby móc go zdefiniować jako region przygraniczny.

Najczęściej stosowanym kryterium do wyznaczania obszarów przygranicznych jest kryterium administracyjne (por. Kałuski, 1990). Do celów realizowania polityki Europejskiej Współpracy Terytorialnej obszary przygraniczne wyznaczono na poziomie, wspomnianych wyżej, jednostek NUTS 3. Stosowanie kryterium administracyjnego w badaniach naukowych ma dwie podstawowe zalety tj. łatwość gromadzenia danych i powtarzalność badań oraz możliwość zastosowania badań teoretycznych w polityce regionalnej (Dołzbłasz i Raczyk, 2010). Ułomnością takiej delimitacji jest natomiast zakwalifikowanie do poszczególnych programów współpracy transgranicznej obszarów niemających żadnych powiązań transgranicznych w danym obszarze współpracy (np. podregion przemyski należący do EWT Polska-Słowacja, który nawet nie graniczy ze Słowacją). Ponadto znaczna powierzchnia podregionów sprawia (dodatkowo przy dużej ich rozciągłości), że obejmują one obszary poza bezpośrednim oddziaływaniem granicy państwowej.

Kryterium administracyjne stosuje się dla różnych poziomów hierarchicznych. Obszarami (regionami) przygranicznymi mogą być zarówno większe (np. województwa sprzed podziału administracyjnego w 1999 r.) jak i mniejsze jednostki administracyjne (np. gminy, powiaty). Problemy z przyjęciem dużych jednostek (NUTS 2) polegają na ich różnicach w powierzchni w poszczególnych krajach (Kałuski, 1990) (niektóre z krajów w całości byłyby obszarami przygranicznymi np. Słowacja, Łotwa). W przypadku małych jednostek administracyjnych (LAU 1 i LAU 2) w Polsce przyjmuje się zazwyczaj pas dwóch gmin lub pas jednego powiatu przylegającego bezpośrednio do granicy państwowej (Leśniak 2006 za Dołzbłasz i Raczyk, 2010; por. także badania GUS, np. GUS, 2017). 
Także delimitacja obszarów przygranicznych (strefy przygranicznej) dla małego ruchu granicznego, co zrozumiałe, bazuje na podziale administracyjnym. W strefie Schengen za strefę przygraniczną uznaje się obszar leżący w odległości 30 km od granicy państwowej. Jeśli jednak część którejkolwiek jednostki administracyjnej (gminy) położona jest między 30 a 50 km od granicy, uznaje się ją za część strefy przygranicznej (Rozporzq̨dzenie WE, 2006). Według GUS (2017) strefa przygraniczna obejmuje powiaty i miasta na prawach powiatu, których siedziba władz zlokalizowana jest w miastach położonych w odległości do 50 km od granicy Polski z krajami sąsiadującymi.

Drugim, obok administracyjnego, podstawowym kryterium jest po prostu fizyczna odległość od granicy państwowej. Stosowana jest zazwyczaj do celów operacyjnych tj. wyznacza strefę szczególnej kontroli straży granicznej i innych służb państwowych (np. celnych). Kryterium to stosowane jest m.in. w Stanach Zjednoczonych, gdzie 100-milowa strefa graniczna obejmuje nie tylko obszar wzdłuż granicy z Meksykiem i Kanadą, ale również wzdłuż zachodniego i wschodniego wybrzeża kraju. W konsekwencji w strefie przygranicznej mieszka 2/3 populacji kraju, to jest ponad 200 milionów osób (ACLU, 2019). Niektóre stany (np. Floryda, Maine, New Hampshire, Rhode Island, Connecticut, Massachusetts) w całości leżą w strefie przygranicznej. W przypadku stosowania takiego kryterium bardzo utrudnione jest prowadzenie badań naukowych, gdyż brak jest odniesienia do jednostek administracyjnych.

Żaden z wymienionych podziałów, czy to bazujący na kryterium administracyjnym lub też uwzględniający fizyczną odległość od granicy, nie obejmuje rzeczywistych powiązań funkcjonalnych. Faktyczny zasięg oddziaływania granicy wskazują powiązania społeczno-gospodarcze, które mają specyficzny charakter w porównaniu z pozostałą częścią kraju (Węcławowicz i inni, 2006). Wydaje się, że to one powinny być podstawą do wskazania istnienia lub nie obszaru przygranicznego i jego szczegółowej, wielokryterialnej delimitacji. Z całą pewnością stanowią one kluczowy element przy próbie oceny bilansu korzyści i niekorzyści lokalizacji przygranicznej. W tym wypadku bardzo istotne jest jednak równoległe zwrócenie uwagi na układ interakcji wewnętrznych. Niekorzyści położenia przy granicy państwa są bowiem tym większe, im bardziej peryferyjne wewnętrznie jest położenie danej jednostki. Pozwala to na wskazanie obszarów przygranicznych o charakterze problemowym oraz tych które przygranicznymi są tylko z racji swego geograficznego położenia i dla których granica nie jest barierą rozwojową oraz nie stanowi o ich peryferyjności.

\section{Propozycja nowego podejścia metodycznego i dyskusja przykładowych wyników dla Polski}

Jak wykazano, problem delimitacji obszarów przygranicznych jest złożony, bowiem położenie przy granicy państwowej niesie ze sobą zarówno szanse, jak i zagrożenia rozwojowe. Dlatego punktem wyjścia analizy było proste wyznaczenie obszarów położonych wzdłuż granic, a następnie eliminacja z tego zbioru jednostek, których sytuacja jest korzystna z uwagi na benefity płynące z interakcji transgranicznych (korzyść położenia przy granicy) lub z uwagi na dogodne położenie wewnętrzne (dobra dostępność do rynków pracy, usług wyższego rzędu itd.).

Problemem było przyjęcie odpowiedniej jednostki delimitacji. Wyjściowo testowano zarówno gminy (dwa pasy: gminy przylegające do granicy oraz jednostki sąsiadujące 
z nimi), jak też powiaty (jeden pas). Uznano, że delimitacja na poziomie gminnym jest właściwsza z uwagi na bardziej regularny przebieg granicy „wewnętrznej” strefy przygranicznej. Ponadto w rzeczywistości problemy związane z położeniem przygranicznym dotyczą często nie tylko jednostek bezpośrednio sąsiadujących z granicą. Ich wyznacznikiem jest raczej niesymetryczność szeroko rozumianego zaplecza społeczno-gospodarczego

W kolejnym kroku z wyznaczonego zbioru wyeliminowano jednostki znajdujące się w korzystnym położeniu względem ośrodków regionalnych, które można utożsamiać z atrakcyjnymi rynkami pracy oraz z centrami lokalizacji usług wyższego rzędu (inne usługi są z reguły dostępne na poziomie powiatowym i tym samym nie różnicują obszarów przygranicznych). Założono jednocześnie, że o atrakcyjności miast regionalnych decyduje ich wielkość. Przyjęto dwa przedziały wielkości miast - stolic województw. Dla każdej zastosowano inną graniczną izochronę czasu dojazdu samochodem osobowym. Położenie siedziby gminy w obrębie tej izochrony kwalifikowało ją jako mniej zagrożoną przygraniczną peryferializacją, a tym samym eliminowało ją z delimitowanych zbiorów. Takie podejście było zgodne m.in. z założeniami alternatywnej typologii obszarów wiejskich opartej na dostępności ośrodków różnego rzędu (Komornicki i Śleszyński, 2009). Sam podział wielkościowy ośrodków nawiązywał do eksperckiej wersji Koncepcji Przestrzennego Zagospodarowania Kraju (Korcelli i inni, 2010). Wyodrębniono zatem następujące kategorie:

- miasta regionalne o liczbie ludności ponad 250 tys. mieszkańców (istniejące i potencjalne metropolie; 11 ośrodków, z czego w relatywnie bliższym sąsiedztwie obszarów przygranicznych: znalazły się: Szczecin, Wrocław, Katowice, Kraków, Lublin i Białystok) o korzystnym położeniu w obrębie izochrony 45 minut;

- miasta regionalne o liczbie ludności poniżej 250 tys. mieszkańców (7 ośrodków, z czego w sąsiedztwie obszarów przygranicznych były zlokalizowane: Gorzów Wielkopolski, Zielona Góra, Opole, Rzeszów i Olsztyn) - o korzystnym położeniu w obrębie izochrony 30 minut.

Do określenia czasu przejazdu wykorzystano bazy Instytutu Geografii i Przestrzennego Zagospodarowania PAN, przygotowane w ramach prac nad dostępnością przestrzenną (Komornicki i inni, 2018). Zostały one obliczone w oparciu o autorski model prędkości ruchu (Komornicki i inni, 2010). W modelu tym poszczególnym kategoriom dróg przypisano najpierw prędkości wynikające z kodeksu drogowego, a następnie obniżano zależnie od trzech czynników: a) przejścia przez obszar zabudowany, b) ukształtowania powierzchni (średnie nachylenie stoków) oraz c) liczby ludności zamieszkałej w buforze 5 km od linii drogi. Przy obniżaniu stosowano zasadę najsłabszego ogniwa (dla danego odcinka drogi przyjmowano największą redukcję prędkości, spośród obliczonych na podstawie wymienionych kryteriów).

W efekcie do wyeliminowania zakwalifikowały się przede wszystkim gminy w rejonie Szczecina, co było zrozumiałe z uwagi na bezpośrednio przygraniczne położenie miasta (ryc. 1). Kryterium położenia w zasięgu oddziaływania dużego ośrodka miało także znaczenie w przypadku kilku gmin położonych przy granicy z Białorusią o krótkim czasie dojazdu do Białegostoku, a ponadto w dwóch jednostkach na pograniczu czeskim o dobrej dostępności do Katowic. Spośród mniejszych miast regionalnych czynnik powiązań wewnętrznych trzeba było uwzględnić w przypadku jednostek pozostających w oddziaływaniu Gorzowa Wielkopolskiego (jedna gmina) i Opola (dwie gminy).

W kolejnym etapie ze zbioru eliminowane były jednostki gminne położone w powiatach o wysokiej relatywnej wartości eksportu do kraju sąsiedniego (analizę wykonano 


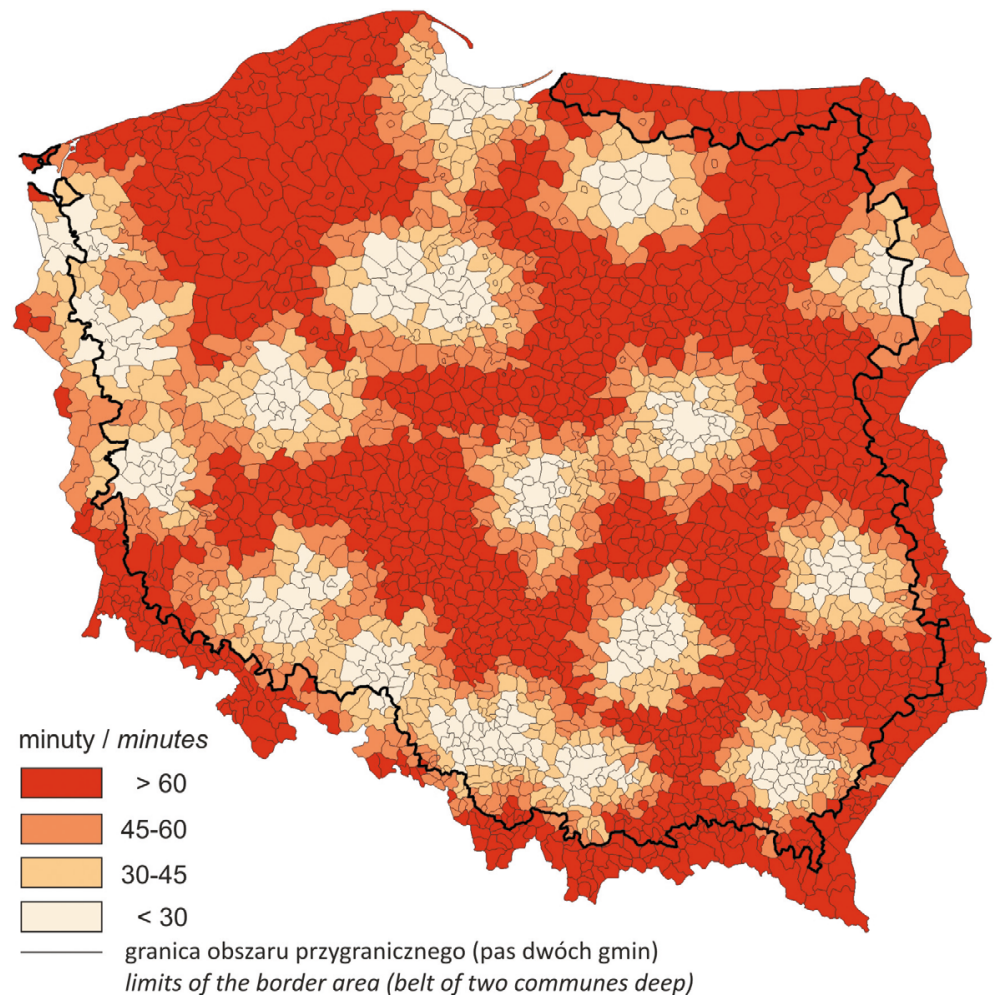

Ryc. 1. Czas dojazdu do ośrodków wojewódzkich (2012)

Time needed to travel to voivodship centres in 2012

Opracowanie własne na podstawie danych IGiPZ PAN / Authors' own elaboration based on IGSO PAS data.

na podstawie danych Ministerstwa Finansów) (ryc. 2). Uznano, że są to jednostki, które na położeniu przygranicznym raczej zyskują niż tracą. Przyjęto, że wartość brzegowa tych korzyści musi być inna na granicach wewnętrznych i zewnętrznych UE. Testowano poziomy 250, 500 i 1000 USD na 1 mieszkańca powiatu. W przypadku powiatów sąsiadujących z dwoma krajami brano pod uwagę eksport do obydwu państw. Uzyskany obraz przestrzenny zadecydował o zaproponowaniu następujących warunków brzegowych eliminacji:

- granica zewnętrzna UE - 500 USD na 1 mieszkańca,

- granica wewnętrzna UE - 1000 USD na 1 mieszkańca.

W analizie bazowano na danych o wartości eksportu pochodzących z zasobów Ministerstwa Finansów. Celowo zastosowano historyczne dane z roku 2009, który był rokiem spowolnienia w ogólnie szybkim wzroście wartości polskiego eksportu. Spowolnienie to spowodowane było globalnym kryzysem ekonomicznym z 2008 r. Przyjęto, że relatywnie wysokie poziomy eksportu w najtrudniejszym ekonomicznie z dostępnych przekrojów czasowych, są dowodem na trwałe korzyści gospodarcze położenia przygranicznego. Takie założenie wynikało z innych analiz handlu zagranicznego na poziomie powiatowym (Komornicki i inni, 2015) dowodzących, iż w niektórych jednostkach przygranicznych poziom 


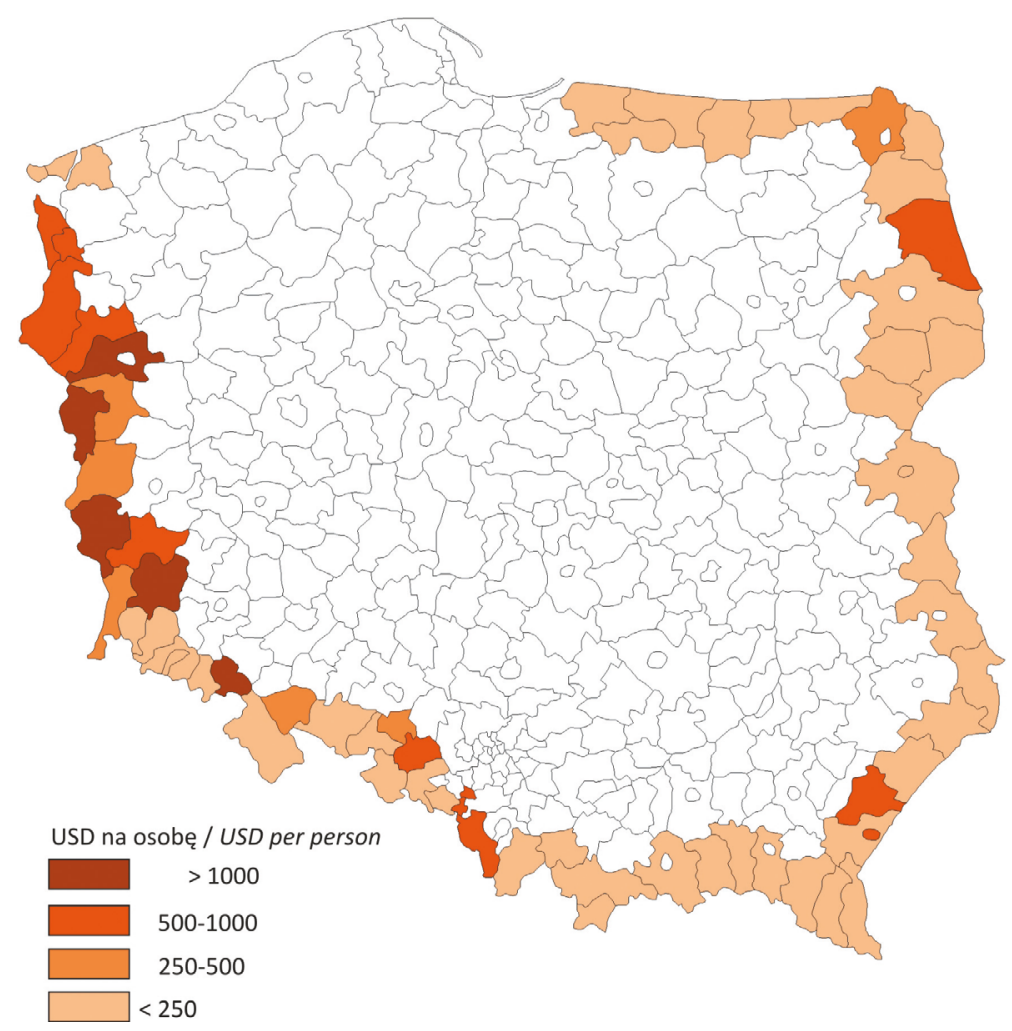

Ryc. 2. Poziom wymiany handlowej (eksport) z krajem sąsiednim w pasie powiatów przygranicznych (2009) Level of export with the neighbouring country in the belt of Polish border poviats, 2009 Opracowanie własne na podstawie danych GUS.

Authors' own elaboration based on data from GUS (Statistics Poland).

obrotów handlowych z zagranicą jest bardzo silnie uzależniony od cykli koniunkturalnych. Do badania wykorzystano dane o eksporcie, pomijając import. Założono, że o ile w przypadku eksportu większość jego wartości przypada na producentów towarów (blisko 90\%; Szejgiec i Komornicki, 2015; Komornicki i Szejgiec-Kolenda, 2017), to w imporcie dominują firmy pośredniczące, silnie skoncentrowane w dużych metropoliach.

$\mathrm{Na}$ tej zasadzie wyłączeniu podlegały gminy przygraniczne położone w ośmiu powiatach (ryc. 2). Były to przede wszystkim powiaty zlokalizowane w sąsiedztwie granicy polsko-niemieckiej (bolesławiecki, żagański, słubicki, gorzowski). Jest to obszar silnej dominacji partnera niemieckiego w handlu zagranicznym. Wiele powiązań ma charakter lokalny, inne wewnątrz-korporacyjny. Na całej granicy południowej (z Czechami i Słowacją) eliminacji z badanego zbioru podlegał jedynie powiat wałbrzyski (w badanym okresie wraz z miastem Wałbrzych, które nie miało wówczas statusu miasta na prawach powiatu). W powiecie znajduje się Wałbrzyska Specjalna Strefa Ekonomiczna oraz przedsiębiorstwa motoryzacyjne współpracujące klastrowo z firmami zlokalizowanymi po czeskiej stronie granicy. Wzdłuż granicy wschodniej kryterium korzyści z wymiany z krajem sąsiednim spełniły trzy powiaty: sokólski na granicy białoruskiej oraz jarosławski i m. Przemyśl - na ukra- 
ińskiej. We wszystkich tych przypadkach korzyści wynikały przede wszystkim z lokalizacji pośredników, tzn. podmiotów zajmujących się reeksportem dóbr poza granicę wschodnią (Szejgiec-Kolenda, 2018).

Niezależnie od opisanych eliminacji gmin z badanego zbioru możliwe jest wskazanie innych jednostek, gdzie rola wymiany z sąsiadem była stosunkowo wysoka (można przyjąć, że także tam rośnie znaczenie korzyści położenia przygranicznego). Należą do nich wszystkie pozostałe jednostki wzdłuż granicy niemieckiej (poza Świnoujściem), tj. powiaty: nyski, krapkowicki, kędzierzyńsko-kozielski, miejski Jastrzębie Zdrój, a także powiat cieszyński na granicy czeskiej oraz suwalski na litewskiej. Czynnik wymiany handlowej z krajem sąsiednim okazał się zatem widoczny (jako korzyść położenia przygranicznego) przede wszystkim na granicy niemieckiej, a ponadto lokalnie na czeskiej, ukraińskiej i białoruskiej. Perspektywicznie, prawdopodobnie może on mieć znaczenie na granicy z Litwą. Przesądzająca o korzyściach, intensywność wymiany handlowej nie została zidentyfikowana na granicy z Rosją i Słowacją.

Na rycinie 3 przedstawiono wynikową delimitację przeprowadzoną z zastosowaniem alternatywnej metodologii (dwa pasy gmin z eliminacją jednostek w oddziaływaniu ośrodków regionalnych oraz tych, dla których wymierne korzyści przynosi wymiana handlowa

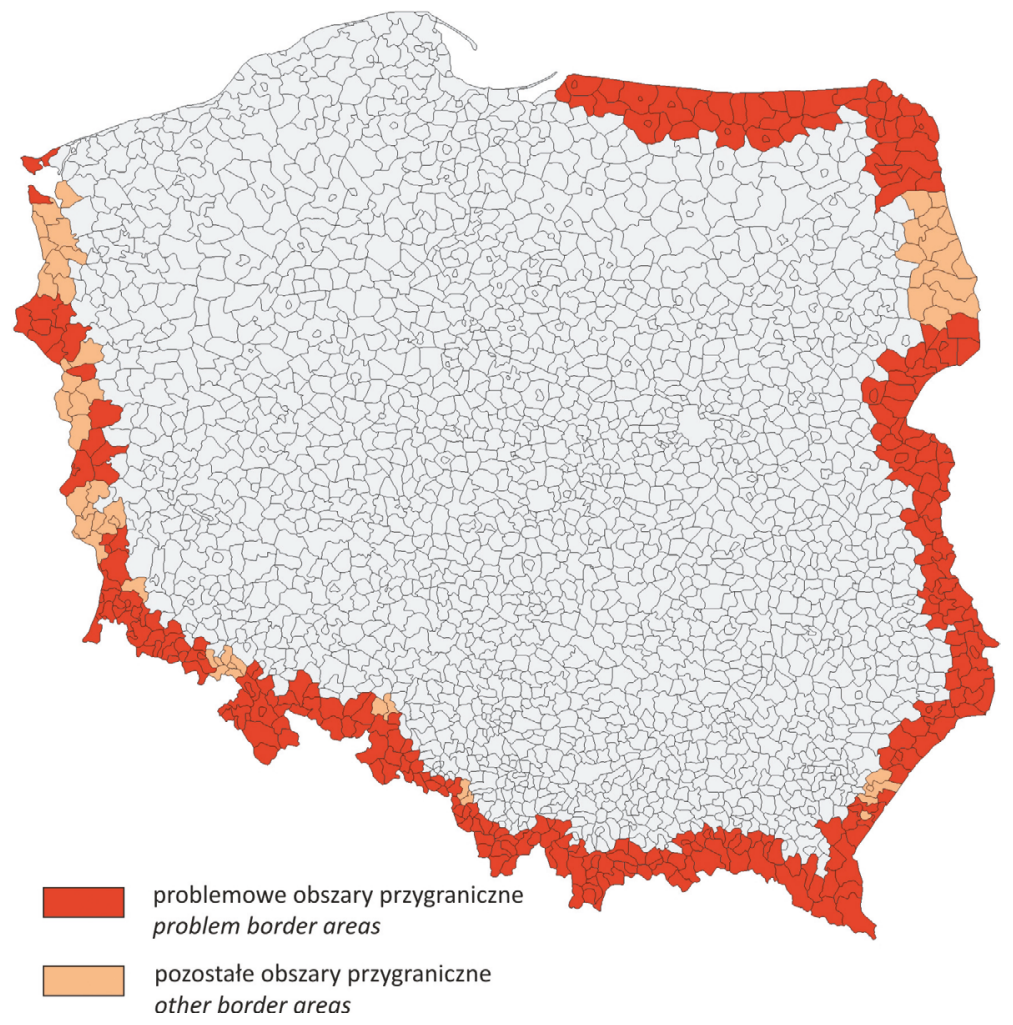

Ryc. 3. Wynikowa propozycja delimitacji obszarów przygranicznych Resulting proposal for the delimitation of border areas Opracowanie własne / Authors' own elaboration. 
z bezpośrednim sąsiadem). Efektem końcowym jest wyznaczeniem strefy najbardziej potrzebującej ewentualnego wsparcia ze strony władz publicznych, w tym wsparcia Unii Europejskiej. Spośród 362 gmin położonych w pierwszym i drugim pasie przygranicznym, wykluczeniu z uwagi na dobry dostęp do ośrodków regionalnych podlegało 21 jednostek, a z uwagi na intensywny handel z sąsiadem 37 jednostek. Dwie gminy spełniały oba kryteria eliminacji. W efekcie liczba gmin przygranicznych wymagających potencjalnego wsparcia zmniejszyła się do 306.

Uzyskany obraz wskazuje na silne zróżnicowanie sytuacji na poszczególnych odcinkach granicznych. Możliwe jest wyróżnienie trzech ich typów:

- granice „korzyści” z mniejszościowym udziałem gmin przygranicznych wymagających wsparcia (w polskich warunkach jest to tylko granica niemiecka);

- granice umiarkowanych „niekorzyści” z mniejszościowym udziałem jednostek przygranicznych o wyraźnie mniejszych problemach (granica czeska, ukraińska, białoruska);

- granice znacznych „niekorzyści”, gdzie wszystkie jednostki przygraniczne mogą wymagać wsparcia strategicznego.

Przy ostatecznym wyznaczaniu obszarów problemowych (dla celów polityki spójności lub innych działań wspierających) zaproponowany podział powinien być brany pod uwagę. Jest przy tym charakterystyczne, że obszary problemowe to nie tylko jednostki położone wzdłuż słabo przepuszczalnej granicy wschodniej, gdzie potencjalne kontakty i przepływy utrudniają bariery formalne, ale również wzdłuż granicy południowej, gdzie m.in. uwarunkowania naturalne (m.in. ukształtowanie powierzchni i związany z tym niski poziom dostępności) przyczyniają się do ich peryferyjności i problemów rozwojowych. Na znacznej części tych obszarów dochodzi do nakładania się różnorodnych problemów m.in. demograficznych i infrastrukturalnych, a także w zakresie dostępności do usług. Natomiast w dużej części obszaru przygranicznego na granicy zachodniej położenie nie stanowi już problemu rozwojowego bądź też jest niwelowane dobrą dostępnością do dużych rynków pracy. Rozkład stref problemowych na granicy niemieckiej wykazuje także zbieżność z wynikami uzyskanymi podczas wyznaczania gmin zagrożonych trwałą marginalizacją (na potrzeby Strategii Odpowiedzialnego Rozwoju; por. Śleszyński i inni, 2017; Bański i inni, 2018). Dotyczy to zwłaszcza położonego przy granicy niemieckiej podobszaru gubińskiego zagrożonego trwałą marginalizacją.

\section{Podsumowanie i rekomendacje}

Sytuacja obszarów przygranicznych na terenie Unii Europejskiej ulega przemianom wynikającym zarówno z przesłanek geopolitycznych, jak też gospodarczych i infrastrukturalnych. Przedstawione wyniki badań potwierdziły, że ma miejsce polaryzacja w tym zakresie. Nie jest ona jedynie pochodną polaryzacji reżimów granicznych, jaka dokonała się z chwilą przystąpienia większości państw Europy Środkowo-Wschodniej do strefy Schengen. Istotną rolę odgrywają także czynniki konkretnej lokalizacji (względem dużych ośrodków) oraz lokalny potencjał do międzynarodowej (transgranicznej) współpracy gospodarczej. Wielowymiarowość polaryzacji zaczęła być dostrzegana przez politykę przestrzenną zarówno na poziomie Unii Europejskiej, jak na poziomie krajowym. Przejawem może być wspomniane wyżej podjęcie prac nad delimitacją obszarów zagrożonych trwałą margina- 
lizacją, jako ewentualnej podstawy dla przyszłego terytorialnego programu operacyjnego UE (lub alternatywnie dla wyodrębnienia innych form dystrybucji środków pomocowych dla takich obszarów w przyszłych regionalnych programach operacyjnych). Nadal jednak dominuje postrzeganie obszarów przygranicznych w dwóch podstawowych kontekstach:

- jako obszarów peryferyjnych (zgodnie z koncepcją rdzeń-peryferie), a w konsekwencji problemowych, wymagających wsparcia ze strony tradycyjnie rozumianej polityki regionalnej (transfer środków);

- jako podmiotu współpracy transgranicznej, wspieranej często z przyczyn politycznych i nie zawsze przekładającej się na realne działania (w tym inwestycyjne).

Równolegle polityka transportowa szczebla UE i krajowego postrzega transgraniczność głównie przez pryzmat dużych inwestycji infrastrukturalnych (sieci transeuropejskie). Rzeczywistość okazuje się bardziej skomplikowana. Granice przenikalne (wewnątrz strefy Schengen) mogą zyskać ponownie wymiar strefy, co można porównać do klasycznych frontires. Nowoczesne frontiers to już jednak nie słabo zaludnione strefy kresowe, ale rozwinięty obszar, na którym przenika się oddziaływanie ośrodków położonych po obu stronach granicy (np. dzięki wspólnemu transgranicznemu planowaniu przestrzennemu). Ta korzystna transformacja jest jednak selektywna przestrzennie. Wraz z zanikiem bariery formalno-prawnej, wzajemne relacje ponownie kształtuje tam bariera infrastrukturalna lub nawet fizyczno-geograficzna. Inwestycje po obu stronach granicy oddziaływają na siebie wzajemnie. Mogą one niekiedy determinować podstawy rozwoju gospodarki lokalnej w kraju sąsiada (por. Miszczuk i Jakubowski, 2019). Dlatego korzyści na granicy niemieckiej i fragmentarycznie na czeskiej okazują się większe niż np. na słowackiej.

Jednocześnie wzdłuż granic, na których nastąpiła ponowna silna formalizacja (granica zewnętrzna UE), sytuacja również ulega różnicowaniu, gdyż 30-letni okres transformacji, oraz funkcjonowanie ułomnych rynków sąsiednich, spowodowało, że niektóre przygraniczne gospodarki lokalne wykształciły zdolność czerpania korzyści z sąsiedztwa twardej i nieprzenikalnej granicy. W warunkach niestabilności w Europie Wschodniej pozostają one jednak gospodarkami o silnej ekspozycji na ryzyko geopolityczne. Pomimo zachowania silnych kontaktów w okresie kryzysowym (rok 2009), jednostki te są prawdopodobnie nadmiernie zależne ekonomicznie od koniunktury na Ukrainie lub Białorusi.

Przedstawione rozważania prowadzą do wniosku, że działania względem obszarów przygranicznych wymagają większego zróżnicowania, które utożsamiać można z proponowaną na poziomie UE terytorializacją polityk rozwojowych. Zależnie od położenia i lokalnych uwarunkowań pomoc ta może opierać się nie tylko na rozwoju lokalnie istotnych gałęzi gospodarki (np. turystyki, rolnictwa), ale także obejmować:

- poprawę dostępności transportowej do krajowych ośrodków regionalnych (możliwości w tym zakresie istnieje zwłaszcza w województwie podkarpackim i lubelskim, ale także w opolskim, dolnośląskim i lubuskim);

- integrację transgranicznych rynków pracy i rynków usług (Jakubowski i inni, 2017; także z wykorzystaniem poprawy transportu, przede wszystkim na śląskim odcinku granicy polsko-czeskiej);

- wsparcie dla lokalnych producentów w nawiązywaniu kontaktów handlowych z partnerami w kraju sąsiada (izby handlowe, gwarancje).

Pewnego wsparcia potrzebują także obszary przygraniczne, które obecnie nie są strefami „niekorzyści”. Może być to np. pomoc w większej dywersyfikacji posiadanych rynków zbytu (zmniejszenie wrażliwości na kryzysy międzynarodowe). 
W szerszym ujęciu teoretycznym, należy stwierdzić, że na gruncie geografii politycznej potrzebujemy obecnie bardziej elastycznego podejścia do oceny oddziaływania barier transgranicznych oraz do delimitacji obszarów przygranicznych. W drugim przypadku nie mogą być to wyłącznie kryteria administracyjne ani miary społeczno-gospodarcze. Dogodnymi narzędziami są raczej wskaźniki interakcji przestrzennych, w tym transgranicznych (badane na poziomie lokalnym) oraz miary dostępności (por. np. Dołzbłasz, 2017, 2018). Są one jednocześnie potencjalnym narzędziem do późniejszej ewaluacji polityk rozwojowych w wymiarze transgranicznym.

Artykuł powstał w ramach grantu badawczego pt. Ekonomiczne, społeczne i geopolityczne uwarunkowania ruchu granicznego - podstawy dla modelowania i prognozowania na przykładzie Polski (BORDER-TRAF) finansowanego przez Narodowe Centrum Nauki na podstawie umowy nr UMO-2016-21/B/HS4/03019.

\section{Piśmiennictwo}

ACLU, 2019, 100 Mile Border Zone, American Civil Liberties Union, https://www.aclu.org/ know-your-rights/border-zone/(29.10.2019).

Bański J., Degórski M., Komornicki T., Śleszyński P., 2018, The delimitation of areas of strategic intervention in Poland; a methodological trial and its results, Moravian Geographical Reports, 26, 2, s. 84-94.

Barca F., 2009, An agenda for a reformed Cohesion Policy. A place-based approach to Meeting European Union Challenges and Expectations, Independent Report prepared at the request of Danuta Hübner, Commissioner for Regional Policy. https://www.europarl.europa.eu/meetdocs/2009_2014/documents/regi/dv/barca_report_/barca_report_en.pdf (28.11.2019).

Bartz K., Fuchs-Schündeln N., 2012, The Role of Borders, Languages, and Currencies as Obstacles to Labor Market Integration, European Economic Review, 56 (6), s. 1148-1163.

Böhme K., Doucet P., Komornicki T., Zaucha J., Świątek D., 2011, How to strengthen the territorial dimension of 'Europe 2020' and the EU Cohesion Policy, Report based on the Territorial Agenda 2020, Poland, Ministry of Regional Development, Warsaw.

Camagni R., 2011, Local knowledge, national vision: challenge and prospect for the EU regional policy, [w:] Territorial Dimension of Development Policies, Ministry of Regional Development, Warsaw, s. 75-84.

Christaller W., 1963, Ośrodki centralne w południowych Niemczech, Przegląd Zagranicznej Literatury Zagranicznej, 1, Instytut Geografii PAN, s. 1-72.

Ciok S., 2004, Pogranicze polsko-niemieckie. Problemy współpracy transgranicznej, Wydawnictwo Uniwersytetu Warszawskiego, Wrocław.

Cooper A., Perkins C., 2012, Borders and status-functions. An institutional approach to study the boarders, European Journal of Social Theory, 15 (1), s. 55-71. https://doi. org/10.1177/1368431011423578

Damsgaard O. i inni, 2011, Territorial State and Perspectives of the European Union, Background document for the Territorial Agenda of the European Union 2020, https://ec.europa.eu/regional_policy/sources/policy/what/territorial-cohesion/territorial_state_and_perspective_2011. $p d f(10.10 .2019)$. 
Dołzbłasz S., 2015, Symmetry or asymmetry? Cross-border openness of service providers in Polish-Czech and Polish-German border towns, Moravian Geographical Reports, 23 (1), s. 2-12.

Dołzbłasz S., 2017, Sieci współpracy transgranicznej na pograniczach Polski, Rozprawy Naukowe Instytutu Geografii i Rozwoju Regionalnego Uniwersytetu Wrocławskiego, 40, Wydawnictwo Uniwersytetu Wrocławskiego, Wrocław.

Dołzbłasz S., 2018, A network approach to transborder cooperation studies as exemplified by Poland's eastern border, Geographia Polonica, 91, 1, s. 63-76. https://doi.org/10.7163/GPol.0091

Dołzbłasz S., Raczyk A., 2010, Współpraca transgraniczna w Polsce po akcesji do UE, Wolters Kluwer Polska, Warszawa.

Fedyk W., Meyer B., Potocki J., 2017, Nowa koncepcja zarzq̨dzania regionami turystycznymi, Studia Oeconomica Posnaniensia, 5, 4, s. 50-81. DOI: 10.18559/SOEP.2017.4.3

Gałązka A., Mync A., 1999, Zmiany społeczno-gospodarcze i infrastrukturalne na obszarach przygranicznych w warunkach otwierajacych się granic, [w:] A. Mync, R. Szul (red.), Rola granicy i współpracy transgranicznej w rozwoju regionalnym i lokalnym, Europejski Instytut Rozwoju Regionalnego i Lokalnego, Uniwersytet Warszawski, Warszawa, s. 42-111.

Garcia J.Z., 2003, Directions in border research: an overview, The Social Science Journal, 40, s 523-533. https://doi.org/10.1016/S0362-3319 (03)00066-1

GUS, 2017, Charakterystyka obszarów przygranicznych na terenie Polski. Podmioty gospodarki narodowej w 2016 r., Główny Urząd Statystyczny, Urząd Statystyczny w Rzeszowie, Warszawa.

Hartshorne R., 1933, Geographic and political boundaries in Upper Silesia, Annals of the American Geographers, 23, s. 195-228.

Jakubowski A., 2018, Asymmetry of Economic Development of Cross-Border Areas in the Context of Perception of Near-Border Location, Barometr Regionalny, 16, 2, s. 123-131.

Jakubowski A., Bronisz U., 2015, Granica Unii Europejskiej jako czynnik (dez) aktywizujacy rozwój i konkurencyjność obszarów przygranicznych, [w:] A. Grynia (red.), Wybrane aspekty rozwoju i konkurencyjności nowych krajów członkowskich Unii Europejskiej, Wydział Ekonomiczno-Informatyczny w Wilnie, Uniwersytet w Białymstoku, Wilno, s. 627-639.

Jakubowski A., Miszczuk A., Kawałko B., Komornicki T., Szul R., 2017, The EU's New Borderland. Cross-border relations and regional development, Routledge, Oxon-New York.

Jałowiecki B., 1999, Oddziaływanie granicy na gminy województw przygranicznych. Wyniki badań ankietowych, [w:] A. Mync, R. Szul (red.), Rola granicy i współpracy transgranicznej w rozwoju regionalnym i lokalnym, Europejski Instytut Rozwoju Regionalnego i Lokalnego, Uniwersytet Warszawski, Warszawa, s. 25-41.

Kałuski S., 1990, Problems of delimitations and typology of border regions, Miscellanea Geographica, 4, 1, s. 167-172.

Knotter A., 2014, Perspectives on Cross-Border Labor in Europe: '(Un)familiarity' or 'Push-and-Pull'?, Journal of Borderlands Studies, 29, 3, s. 319-326. https://doi.org/10.1080/08865655.2014.93 8972

Kolosov V., 2005, Border studies: Changing perspectives and theoretical approaches, Geopolitics, 10, 4, s. 606-632. https://doi.org/10.1080/14650040500318415

Kolosov V., Więckowski M., 2018, Border changes in Central and Eastern Europe: an introduction, Geographia Polonica, 91, 1, s. 5-16. https://doi.org/10.7163/GPol.0106

Komornicki T., 1999, Granice Polski. Analiza zmian przenikalności w latach 1990-1996, Geopolitical Studies, 5, Instytut Geografii i Przestrzennego Zagospodarowania PAN, Warszawa. 
Komornicki T., 2002, Euroregiony wschodniego pogranicza a oficjalna wymiana towarowa, [w:] A. Stasiak (red.), Euroregiony wschodniego pogranicza - założenia i osiagnięcia, Białystok, Wydawnictwo Wyższej Szkoły Ekonomicznej, s. 31-48.

Komornicki T., 2010a, Flows of persons and goods across the Polish segment of the outer boundary of the European Union - results of a research project, [w:] European Union external and internal borders interactions and networks, EUROPA XXI, 20, s. 9-29.

Komornicki T., 2010b, Transborder transport, [w:] K. Button, H. Vega, P. Nijkamp (red.), A dictionary of transport analysis, Edward Elgar Publishing Limited, Cheltenham, Northampton.

Komornicki T., Rosik P., Stępniak M., Śleszyński P., Goliszek S., Pomianowski W., Kowalczyk K., 2018, Ewaluacja i monitoring zmian dostępności transportowej w Polsce z wykorzystaniem wskaźnika WMDT, Ministerstwo Inwestycji i Rozwoju, Warszawa.

Komornicki T., Śleszyński P., 2009, Typologia obszarów wiejskich pod względem powiqzań funkcjonalnych i relacji miasto-wieś, [w:] J. Bański (red.), Analiza zróżnicowania i perspektyw rozwoju obszarów wiejskich w Polsce do 2015 roku, Studia Obszarów Wiejskich, 16, Polskie Towarzystwo Geograficzne, Instytut Geografii i Przestrzennego Zagospodarowania PAN, Warszawa, s. 9-37.

Komornicki T., Śleszyński P., Rosik P., Pomianowski W., 2010, Dostępność przestrzenna jako przesłanka kształtowania polskiej polityki transportowej, Biuletyn, 241, Komitet Przestrzennego Zagospodarowania Kraju PAN, Warszawa.

Komornicki T., Szejgiec-Kolenda B., 2017, Przekształcenia przestrzennego rozmieszczenia obszarów koncentracji eksportu w Polsce, Przegląd Geograficzny, 89, 2, s. 269-289.

Komornicki T., Wiśniewski R., 2017, Border traffic as a measure of trans-border relations, Mitteilungen der Österreichischen Geographischen Gesellschaft, 159, s. 151-172.

Komornicki T., Zaucha J., Szejgiec B., Wiśniewski R., 2015, Powiqzania eksportowe gospodarki lokalnej w warunkach zmiennej koniunktury - analiza przestrzenna, Prace Geograficzne, 250, Instytut Geografii i Przestrzennego Zagospodarowania PAN, Warszawa.

Korcelli P., Degórski M., Drzazga D., Komornicki T., Markowski T., Szlachta J., Węcławowicz G., Zaleski J., Zaucha J., 2010, Ekspercki projekt Koncepcji Przestrzennego Zagospodarowania Kraju do roku 2033, Studia, 128, Komitet Przestrzennego Zagospodarowania Kraju PAN, Warszawa.

Koter M., 2003, Multicultural Border Regions of Europe - Forms of Ethnic Composition and Process of their Differentiation, Region and Regionalism, 6, 1, s. 13-22.

KPZK 2030, 2012, Koncepcja Przestrzennego Zagospodarowania Kraju 2030, Ministerstwo Rozwoju Regionalnego, Warszawa.

Leśniak M., 2006, Konkurencyjność obszarów pogranicza polsko-niemieckiego, rozprawa doktorska, Zakład Zagospodarowania Przestrzennego, Uniwersytet Wrocławski, Wrocław.

Medeiros E., 2018, Should EU cross-border cooperation programmes focus mainly on reducing border obstacles? Documents d'Anàlisi Geogràfica, 64, 3, s. 467-491. https://doi.org/10.5565/rev/ dag. 517

Miszczuk A., 2013, Uwarunkowania peryferyjności region przygranicznego, Norbertinum, Lublin.

Miszczuk A., Jakubowski A., 2019, Borders and Border Cities in Transitions: Toward a Typology, Barometr Regionalny, 17, 1, s. 7-14. https://doi.org/10.35480/BRAiP-2019.17.1-720

Plan zagospodarowania przestrzennego województwa lubelskiego, 2002, Kierunki polityki przestrzennej, tom. II. http://www.plan.lubelskie.pl/Tom_2/Roz2_02.htm

Powęska H., 2002, Przestrzenny wymiar handlu transgranicznego w Polsce w ostatniej dekadzie XX wieku, Geopolitical Studies, 9, Instytut Geografii i Przestrzennego Zagospodarowania PAN, Warszawa. 
Powęska H., 2011, Struktura towarowa handlu przygranicznego na pograniczu polsko-ukraińskim, Roczniki Naukowe Stowarzyszenia Ekonomistów Rolnictwa i Agrobiznesu, 2, 13, s. 371-376.

Proniewski M., 2014, Polityka rozwoju regionów peryferyjnych, Optimum. Studia Ekonomiczne, 6 (72), s. 79-90.

Raczyk A., Dołzbłasz S., Leśniak-Johann M., 2012, Relacje współpracy i konkurencji na pograniczu polsko-niemieckim, Wydawnictwo Gaskor, Wrocław.

Rajman J., 1993, Problematyka demograficzna i osadnicza w badaniach regionów przygranicznych Polski, [w:] J. Kitowski, Z. Zioło (red.), Czynniki i bariery rozwoju regionów przygranicznych, Wydawnictwo Uniwersytetu Marii Curie-Skłodowskiej, Rzeszów.

Rozporządzenie (WE) nr 1931/2006 Parlamentu Europejskiego i Rady z dnia 20 grudnia 2006 r. ustanawiające przepisy dotyczące małego ruchu granicznego na zewnętrznych granicach lądowych państw członkowskich i zmieniające postanowienia Konwencji z Schengen, 2006. https://eur-lex. europa.eu/legal-content/PL/TXT/PDF/? uri=CELEX: 32006R1931R (01)\&from=LV (29.10.2019).

Sanguin A.L., 1983, L'architecture spatiale des frontiers politiques: quelques reflections theoriques propos de l'exemple Suisse, Regio Basisliensis, 24, s. 1-10.

Skraba A., Nowicka M., 2018, Migration and Migrant Entrepreneurship in a German-Polish border region, Studia Migracyjne - Przegląd Polonijny, 3 (169), s. 17-39.

Śleszyński P., Bański J., Degórski M., Komornicki T., 2017, Delimitacja obszarów strategicznej interwencji państwa: obszarów wzrostu i obszarów problemowych, Prace Geograficzne, 260, Instytut Geografii i Przestrzennego Zagospodarowania PAN, Warszawa.

Sohn C., 2014, The Border as a Resource in the Global Urban Space: A Contribution to the Cross-Border Metropolis Hypothesis, International Journal of Urban and Regional Research, 38, 5, s. 1697-1711. https://doi.org/10.1111/1468-2427.12071

Spierings B., van der Velde M., 2008, Shopping, borders and unfamiliarity: consumer mobility in Europe, Tijdschrift voor Economische en Sociale Geografie, 99, 4, s. 497-505. https://doi. org/10.1111/j.1467-9663.2008.00484.x

Studzieniecki T., Palmowski T., 2019, Delimitacja destynacji turystycznej na przykładzie Regionu Morza Bałtyckiego, Przedsiębiorczość i Zarządzanie, 20, 2, s. 91-107.

Szejgiec B., 2010, Foreign trade commodity flows across the eastern boundary of Poland, [w:] European Union external and internal borders interactions and networks, EUROPA XXI, 20, s. 45-54.

Szejgiec B., Komornicki T., 2015, Spatial differentiation of Polish export linkages, Geographia Polonica, 88,1 , s. 173-178.

Szejgiec-Kolenda B., 2018, Export activity patterns of border regions in Poland, Europa XXI, 34, s. 113-122.

Szymańska E.J., Stefaniak M., 2014, Znaczenie ruchu przygranicznego w rozwoju społeczno-gospodarczym gmin wschodniej Polski, Zeszyty Naukowe Szkoły Głównej Gospodarstwa Wiejskiego, Ekonomika i Organizacja Gospodarki Żywnościowej, 105, s. 45-56.

Territorial Agenda of the European Union 2020 - Towards an Inclusive, Smart and Sustainable Europe of Diverse Regions, 2011, (Agreed at the Informal Ministerial Meeting of Ministers Responsible for Spatial Planning and Territorial Development on 19th May 2011 Gödöllö, Hungary). https://ec.europa.eu/regional_policy/sources/policy/what/territorial-cohesion/territorial_ agenda_2020.pdf (14.11.2019).

Ustawa z dnia 12 października 1990 r. o ochronie granicy państwowej, Dz.U. 1990 nr 78 poz. 461, http://prawo.sejm.gov.pl/isap.nsf/DocDetails.xsp? id=WDU19900780461 (29.10.2019).

Węcławowicz G., Degórski M., Komornicki T., Korzeń J., Bański J., Korzeń J., Soja R., Śleszyński P., Więckowski M., 2006, Studia nad przestrzennym zagospodarowaniem obszaru wzdłuż granicy 
polsko-niemieckiej, Prace Geograficzne, 207, Instytut Geografii i Przestrzennego Zagospodarowania PAN, Warszawa.

Więckowski M., 2004, Przyrodnicze uwarunkowania kształtowania się polsko-słowackich więzi transgranicznych, Prace Geograficzne, 195, Instytut Geografii i Przestrzennego Zagospodarowania PAN, Warszawa.

Więckowski M., 2010, Turystyka na obszarach przygranicznych Polski, Prace Geograficzne, 224, Instytut Geografii i Przestrzennego Zagospodarowania PAN, Warszawa.

Więckowski M., Michniak D., Bednarek-Szczepańska M., Chrenka B., Ira V., Komornicki T., Rosik P., Stępniak M., Szekely V., Śleszyński P., Świątek D., Wiśniewski R., 2012, Polish-Slovak borderlandtransport accessibility and tourism, Prace Geograficzne, 234, Instytut Geografii i Przestrzennego Zagospodarowania PAN, Warszawa.

Wiśniewski R., 2010, The intensity and the structure of the cross-border traffic at the eastern boundary of Poland on the basis of a field study, [w:] European Union external and internal borders interactions and networks, EUROPA XXI, 20, s. 31-44.

Zaucha J., Komornicki T., Świątek D., Böhme K., Żuber P., 2012, Territorial keys for bringing closer the Territorial Agenda of the EU and Europe 2020, European Planning Studies, 22 (2), s. 246-267. https://doi.org/10.1080/09654313.2012.722976

\section{Summary}

While border areas are usually perceived as peripheral in nature, denoting only a limited level of economic development, it is clear that a border location might also be in a position to offer measurable benefit. In that context, work described here in relation to Poland has focused in on: (1) the delimitation of border areas; and (2) an identification and subdivision of units into those whose location by a state border brings either positive or negative economic consequences.

The criterion applied most often in designating border areas is administrative (cf. Kałuski, 1990), with different hierarchical levels referred to (e.g. the NUTS 3 where pursuit of the EU policy on Territorial Cooperation is concerned; or LAU 2 where the need is to designate areas characterised by small-scale border traffic, with account then taken of the criterion of distance of a given administrative unit from the border).

Alongside the administrative, a second main criterion relates simply to physical distance from a border, and usually gains application in denoting a zone of particularly intensive scrutiny by the Border Guard and other state services such as the Customs Administration (e.g. in the United States). Use of this criterion actually does much to hinder scientific research, given the lack of concordance with units of administration.

Neither of the divisions referred to above embraces real functional linkages, while the real-life zone of impact of a border is likely to be indicated by just such linkages, of a socioeconomic nature, and specific in the sense that other parts of a country do not manifest them (Węcławowicz et al., 2006). Such linkages would seem to offer a basis to determine, first, if border areas actually exist at all, and, second, how they can be delimited in a detailed way, by reference to multiple criteria. It is certain that a key aspect is involved here, as the attempt is made to set the benefits of a border location against the "non-benefits". But it is clear that attention also needs to be paid to the configuration of internal interactions, as aspects of a border location become all the more unfavourable the more 
peripherally a given unit is located. Ultimately, it is possible to indicate which border areas are actually problem areas, and to set these apart from other areas by a border whose geographical position ensures that a border represents no barrier to development and/or does not determine peripheral status.

For the above reasons, the work presented here does indeed propose a delimitation based on real economic linkage (levels of export), as well as the degree to which regional centres are accessible from the given area. The first stage of the delimitation procedure thus takes in the designation of a border area formed from a belt of Polish communes (LAU 2) "two deep". A second stage then sees elimination from this set of those units with a favourable location vis-à-vis the nearest regional centre (s), it being assumed that the proximity of these centres helps even out any potentially negative impact of the border; as well as with a high value for the statistic regarding the value of exports to the neighbouring country (the assumption then being that such units benefit from a border location, rather than suffering as a result of it).

Units left behind following the application of this procedure were deemed to be border communes of problem status, potentially in need of support if they are to develop. In the event, such units are found to be located primarily along Poland's borders with the Russian Federation, Lithuania, Belarus and Slovakia (as opposed to Germany, the Czech Republic and Ukraine). Unsurprisingly, it is communes by the Polish-German border that are seen to benefit most from their location.

The authors set other divisions and classifications already in effect against the proposal for delimitation which is offered here, along with relevant recommendations for the development of regional policy. 